\title{
Standards Adoption and Retirement Process Service Action Plan
}



\section{March 1997}

\section{U.S. Department of Energy}


This report has been reproduced directly from the best available copy.

Available to DOE and DOE Contractors from the Office of Scientific and Technical Information, P.O. Box 62, Oak Ridge, TN 37831; prices available from (423) 576-8401.

Available to the public from the U.S. Department of Commerce, Technology Administration, National Technical Information Service, Springfield, VA 22161, (703) 487-4650. 


\section{U.S. Department of Energy Information Architecture}

\section{Standards Adoption and Retirement Process Service Action Plan}

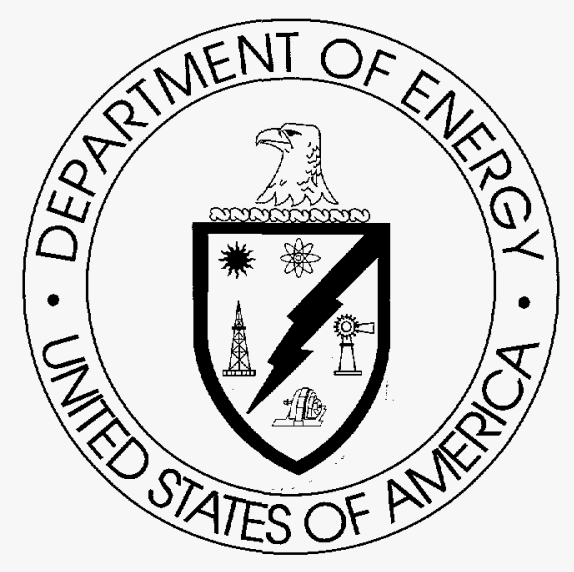

\section{March 1997}

Assistant Secretary for Human Resources and Administration

Deputy Assistant Secretary for Information Management

DISTRIBUTION OF THIS DOCUMENT IS UNLIMITED

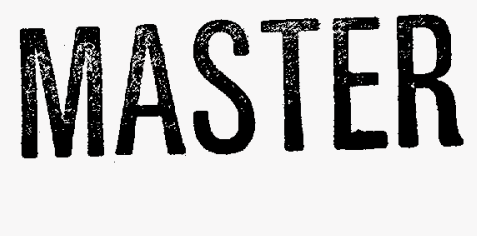




\section{DISCLAMIER}

Portions of this document may be illegible in electronic image products. Images are produced from the best available original document. 


\section{DISCLAIMER}

This report was prepared as an account of work sponsored by an agency of the United States Government. Neither the United States Government nor any agency thereof, nor any of their employees, make any warranty, express or implied, or assumes any legal liability or responsibility for the accuracy, completeness, or usefulness of any information, apparatus, product, or process disclosed, or represents that its use would not infringe privately owned rights. Reference herein to any specific commercial product, process, or service by trade name, trademark, manufacturer, or otherwise does not necessarily constitute or imply its endorsement, recommendation, or favoring by the United States Government or any agency thereof. The views and opinions of authors expressed herein do not necessarily state or reflect those of the United States Government or any agency thereof. 


\section{Foreword}

The Department of Energy (DOE), through the Strategic Alignment Implementation Plan for Information Management, is committed to the development of an enterprisewide information architecture. Achieving the vision of the information architecture requires adopting, implementing, and tracking information technology standards, where appropriate, to assist customers and business partners in fulfilling the Departmental mission and enhancing information infrastructure. Adoption and implementation of standards DOEwide must be consensus-based with active participation of enterprisewide stakeholders.

In support of this commitment, the DOE Chief Information Officer is implementing an Information Architecture Standards Adoption and Retirement Process to meet the needs of the DOE community. Information Technology Standards Points of Contact, as well as Information Management Planning and Architecture Coordinating Team members, are encouraged to participate in information technology standards activities and

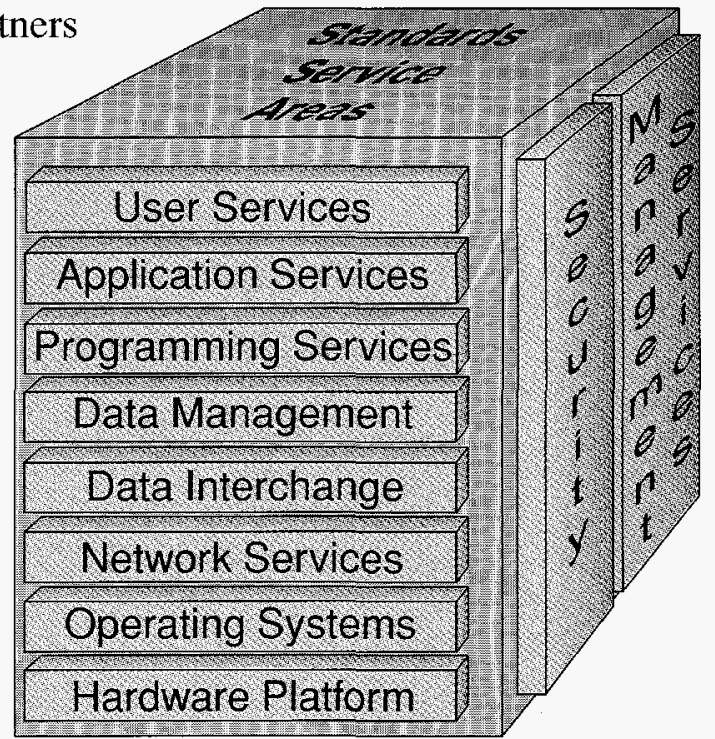
implement and monitor the standards adoption and retirement process described in this Service Action Plan.

The Information Architecture Standards Adoption and Retirement Process also supports the implementation of the National Technology Transfer and Advancement Act of 1995 [Public Law (PL) 104-113], which requires Federal Agencies to use consensus-based standards to carry out policy objectives and activities. Information technology standards that are developed by voluntary, private sector, consensus standards bodies will be promoted through this process to facilitate DOE information architecture implementation. 



\section{Table of Contents}

Foreword $\ldots \ldots \ldots \ldots \ldots \ldots \ldots \ldots \ldots \ldots \ldots \ldots \ldots \ldots \ldots \ldots \ldots$

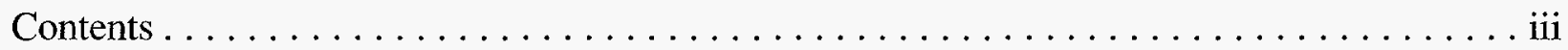

Introduction $\ldots \ldots \ldots \ldots \ldots \ldots \ldots \ldots \ldots \ldots \ldots \ldots \ldots \ldots \ldots \ldots \ldots$





Service Goal. . . . . . . . . . . . . . . . . . . . . . . . . . 2

Strategy . . . . . . . . . . . . . . . . . . . . . . .

Customer and Stakeholder Identification $\ldots \ldots \ldots \ldots \ldots \ldots \ldots \ldots \ldots \ldots \ldots \ldots \ldots \ldots \ldots$

Service Team . . . . . . . . . . . . . . . . . . . . . . . . . 4

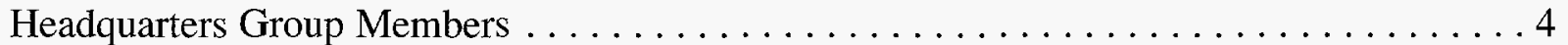

DOE Information Technology Standards Points of Contact. . . . . . . . . . . . . 4

IMPACT Members . . . . . . . . . . . . . . . . . . . . . . . . . 4

DOE Technical Standards Program. . . . . . . . . . . . . . . . . 4

Information Architecture Standards Adoption and Retirement Process . . . . . . . . . . 5

Background . . . . . . . . . . . . . . . . . . . . . . . . . . .

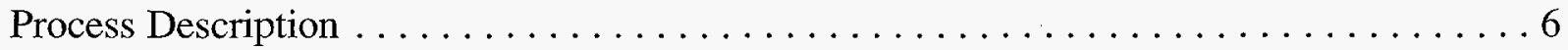

Approach . . . . . . . . . . . . . . . . . . . . . . . 9

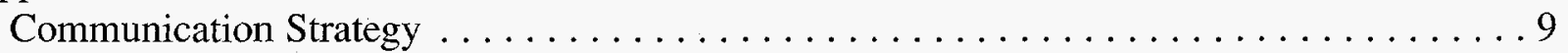



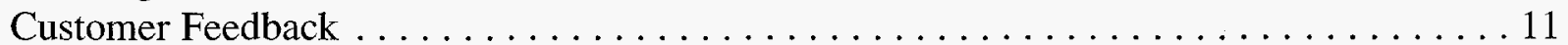

Empowerment Plan . . . . . . . . . . . . . . . . . . . . . . . . . 12

Reinforcement (Rewards, Reminders, and Recognition) . . . . . . . . . . . . 12

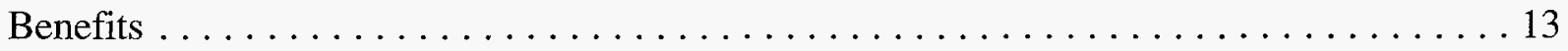

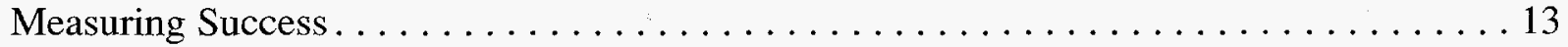

Appendix A - Information Technology Standards Points of Contact . . . . . . . . . . A-1 
The purpose of this Service Action Plan is to announce, as well as provide, a high-level outline of a new Departmental process for the adoption and retirement of information technology standards. This process supports the implementation of a Department of Energy (DOE) Information Architecture.

This plan was prepared with the Department of Energy information technology standards customers and stakeholders in mind. The process described in this plan will be serviced primarily by staff from the Office of the Deputy Assistant Secretary for Information Management with assistance from designated program and site Information Technology Standards Points of Contact.

We welcome any comments regarding this new Departmental process and encourage the proposal of information technology standards for adoption or retirement. To submit comments or standards proposals, contact the DOE Information Technology Standards Program Manager via electronic mail at: carol.blackston@hq.doe.gov. Please also visit the DOE Information Technology Standards World Wide Web (WWW) Home Page for additional information on DOE Information Technology Standards.

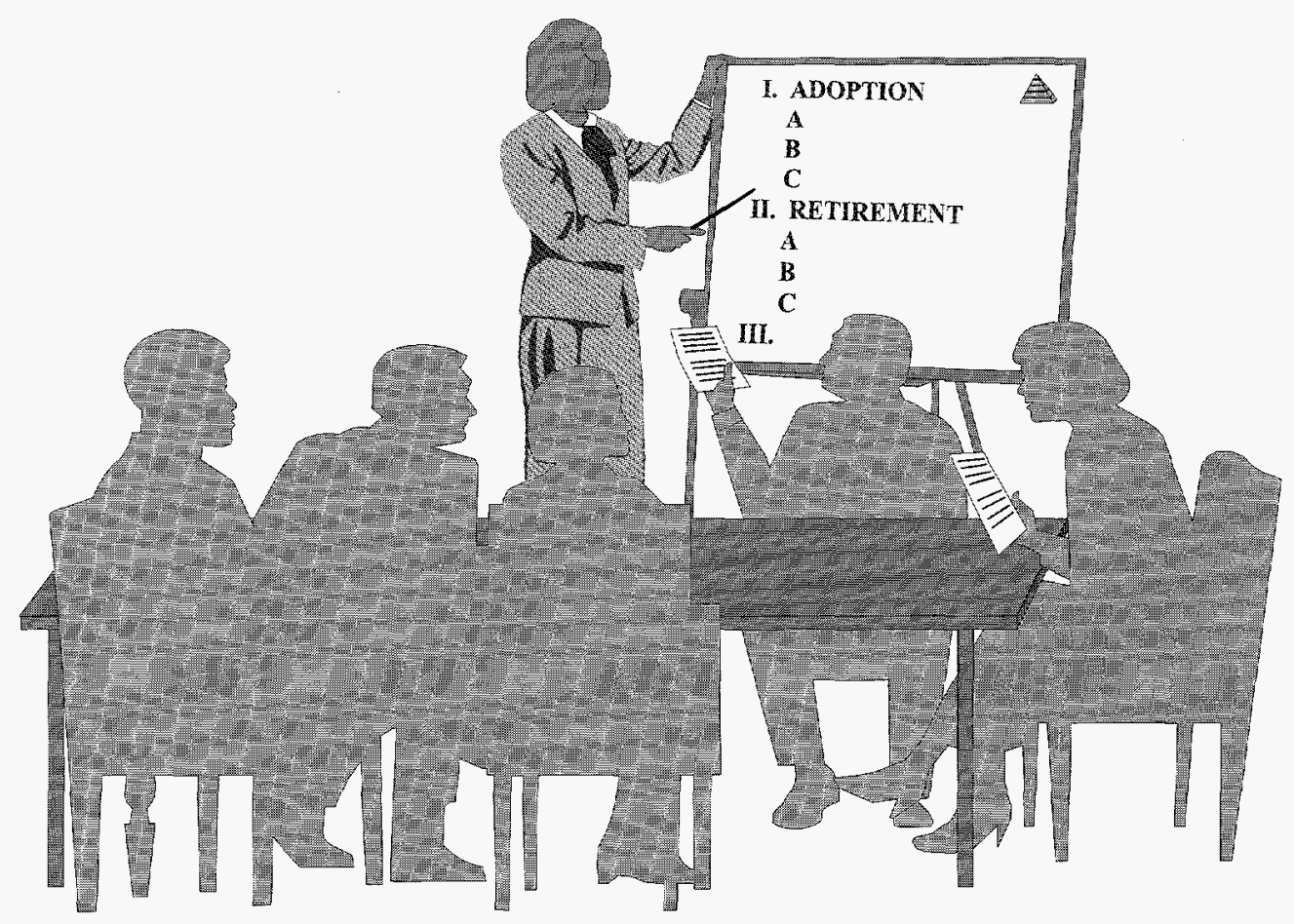




\section{Vision, Service Goal, and Strategy}

\section{VISION}

A process implemented for adopting and retiring information technology standards that aligns with the Departmental information architecture, is timely, creates stakeholder value, and meets customer needs.

\section{SERVICE GOAL}

Provide an open, consensus-based process to implement and withdraw Information Technology (IT) standards that facilitate the sharing of information by enhancing our business partners' ability to interoperate using commercially available computer, communication, and networking equipment and software.

\section{STRATEGY}

Adopt, implement, and retire consensus-based standards with active participation of DOE users. A key component of the strategy is to include users and subject matter experts during evaluation and comment phases to gain their assistance and endorsement. If a proposed standard completes the process cycle and is not approved for adoption or retirement, it will be returned to the originating body or affinity group with an explanation of why it was not approved.

Sunset review dates will be established for all adopted standards. Fast-track efforts will be made to update or retire standards in a timely manner. 


\section{Customer and Stakeholder Identification}

The customers for the standards adoption and retirement process are standards proponents (i.e., affinity groups and functional business areas, such as electronic commerce, video teleconferencing, digital signature, e-mail/file transfer, etc.). When a customer proposes a Departmentwide standard for adoption or retirement, the process cycle begins. Ultimately, every user of Departmental information becomes a stakeholder.

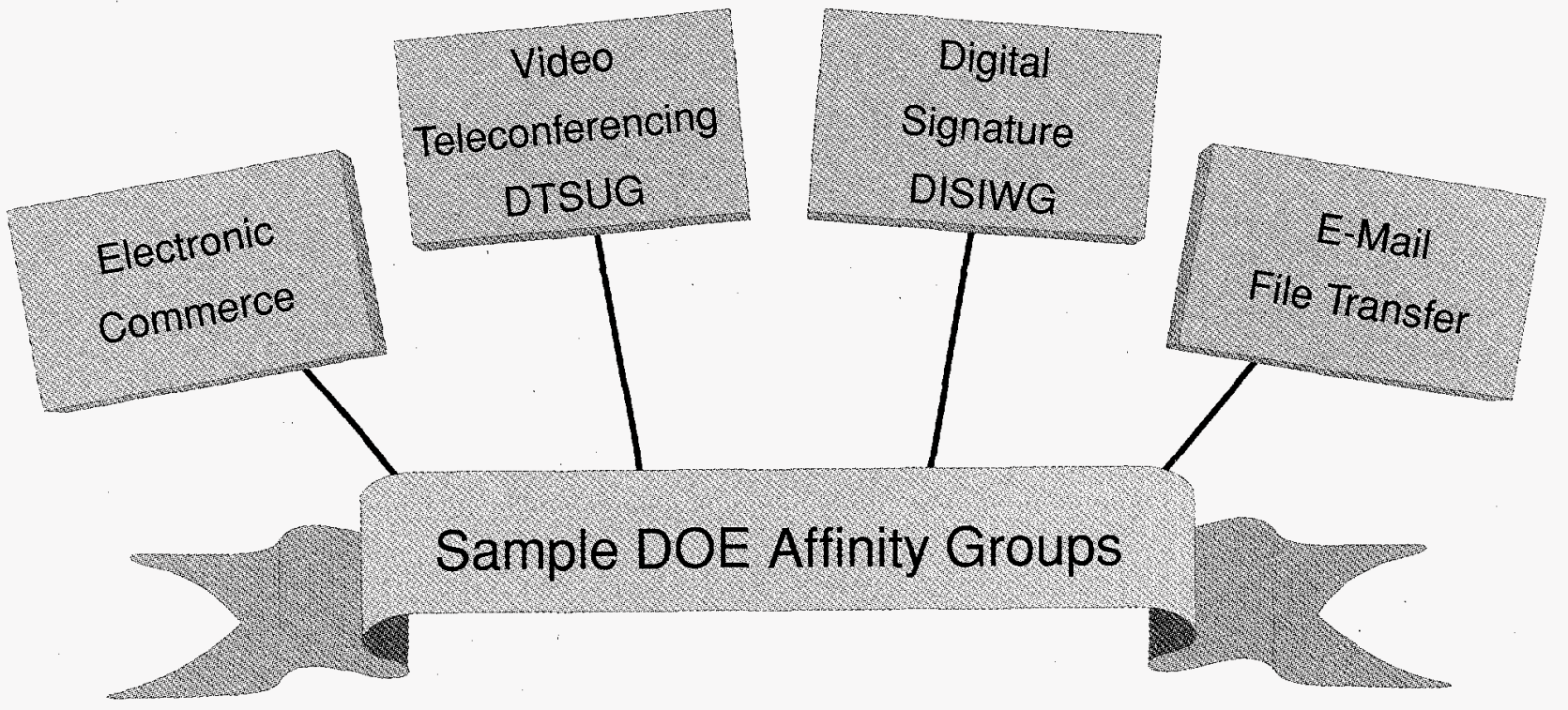




\section{Service Team}

The Service Team for this new process consists of two main components: a core Headquarters Group and designated DOE program and site Information Technology (IT) Standards Points of Contact. Process activities will also be coordinated with the Information Management Planning and Architecture Coordinating Team (IMPACT) and the DOE Technical Standards Program.

\section{HEADQUARTERS GROUP MEMBERS}

Carol Blackston, HR-431, DOE Information Technology Standards Program Manager Michael Tiemann, HR-431, DOE Information Architect Bruce White, HR-431, DOE Information Architecture Team Richard Serbu, EH-31, DOE Technical Standards Program Manager Ovidio O.R. Santivanez, DynCorp

\section{DOE INFORMATION TECHNOLOGY STANDARDS POINTS OF CONTACT}

Points of contact are listed in Appendix A, Information Technology Standards Points of Contact, and are also available through the WWW Information Technology Standards Home Page.

\section{IMPACT MEMBERS}

Information on IMPACT meeting attendees is available via the DOE Information Architecture Home Page.

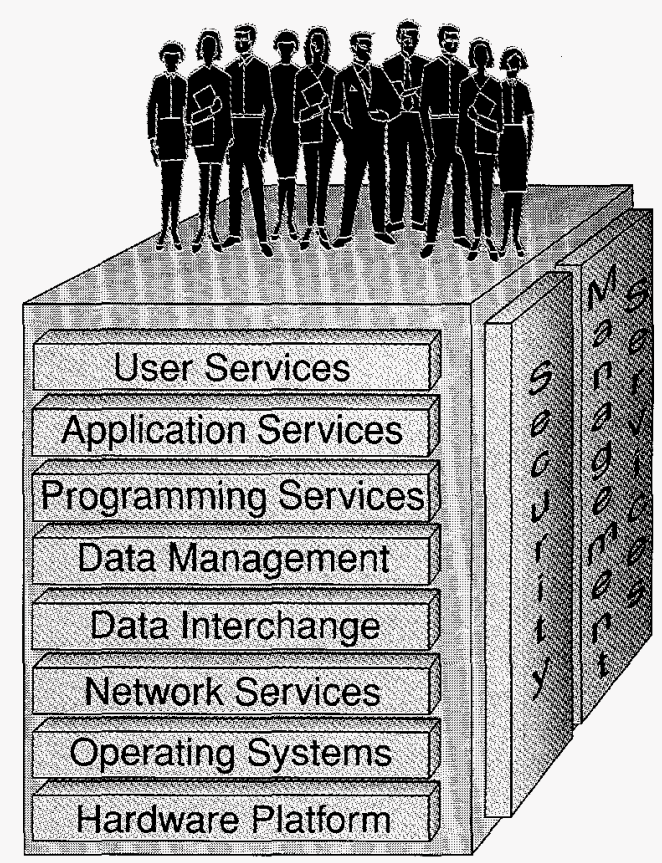

\section{DOE TECHNICAL STANDARDS PROGRAM}

Partnership and coordination activities are ongoing with the DOE Technical Standards Program managed by EH-31, Office of Nuclear Safety Policy and Standards. The DOE Technical Standards Program serves as a central forum for development and distribution of DOE Technical Standards and provides assistance in identifying suitable nongovernment standards. Information architecture standards proposals will be coordinated with the DOE Site Technical Standards Managers. 


\section{Information Architecture Standards Adoption and Retirement Process}

\section{BACKGROUND}

The need for a standards adoption and retirement process was identified during the initial IMPACT meeting held in Idaho Falls, Idaho, in October 1994. The DOE Chief Information Officer (CIO) had tasked the Information Architecture Team to leverage and coordinate efforts of a DOEwide crosscutting team of information management professionals to create and implement a DOE information architecture.

The team identified that information architecture is based on open standards and interoperability principles. The architecture will be implemented cooperatively on a decentralized basis. Adopted standards will be based on a vision that transitions from the current baseline to the target architecture. This process is viewed as a major component of the information architecture concept.

A detailed description of the standards adoption and retirement process that was developed by the team is included in the DOE Information Architecture, Volume I, The Foundations, March 1995. It was further documented during the third IMPACT meeting held in Washington, D.C., in May 1995.

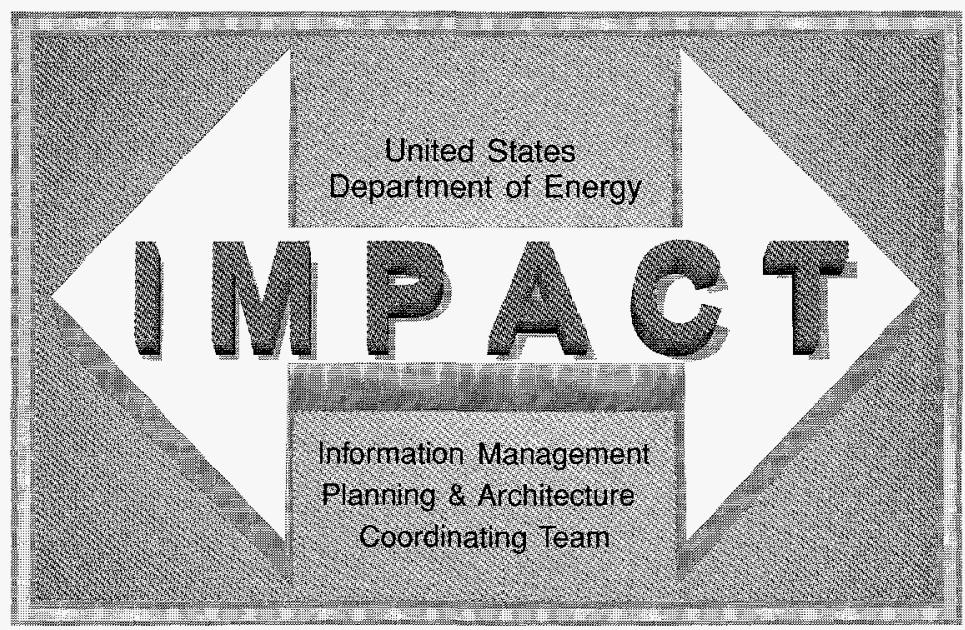




\section{PROCESS DESCRIPTION}

The following are elements in the standards adoption and retirement process:

$\square \quad$ A standard that is being recommended for adoption or retirement is submitted to the DOE Information Technology Standards Program Manager for Departmentwide consideration.

$\square \quad$ Requests for comments are solicited from Headquarters program and site Information Technology Standards Points of Contact, IMPACT members, and subject matter experts.

The Information Technology Standards Program Manager receives comments and forwards a consolidated Departmental response to the originating body. If comments are not received in the specified time frame, consensus is implied.

- The originating body provides resolution on the comments to the Information Technology Standards Program Manager.

$\square \quad$ The Information Technology Standards Program Manager distributes the comments resolution to the Information Technology Standards Points of Contact for response and consensus position for their respective sites.

- If Departmentwide consensus is reached, the standard is designated an interim standard.

The interim standard is forwarded to the DOE Corporate Guidance Group for acceptance and recommendation for approval by the DOE Information Management Council and CIO. If the interim standard is accepted and approved, it becomes an adopted standard.

- If consensus is not reached or if the proposed standard is not accepted by the DOE Corporate Guidance Group, the standard is returned to the originating body.

The following graphic depicts the information architecture standards adoption and retirement process cycle.

Standards Adoption and

Retirement Process

3/97
Department of Energy

Information Architecture 


\section{Information Architecture Standards Adoption and Retirement Process}

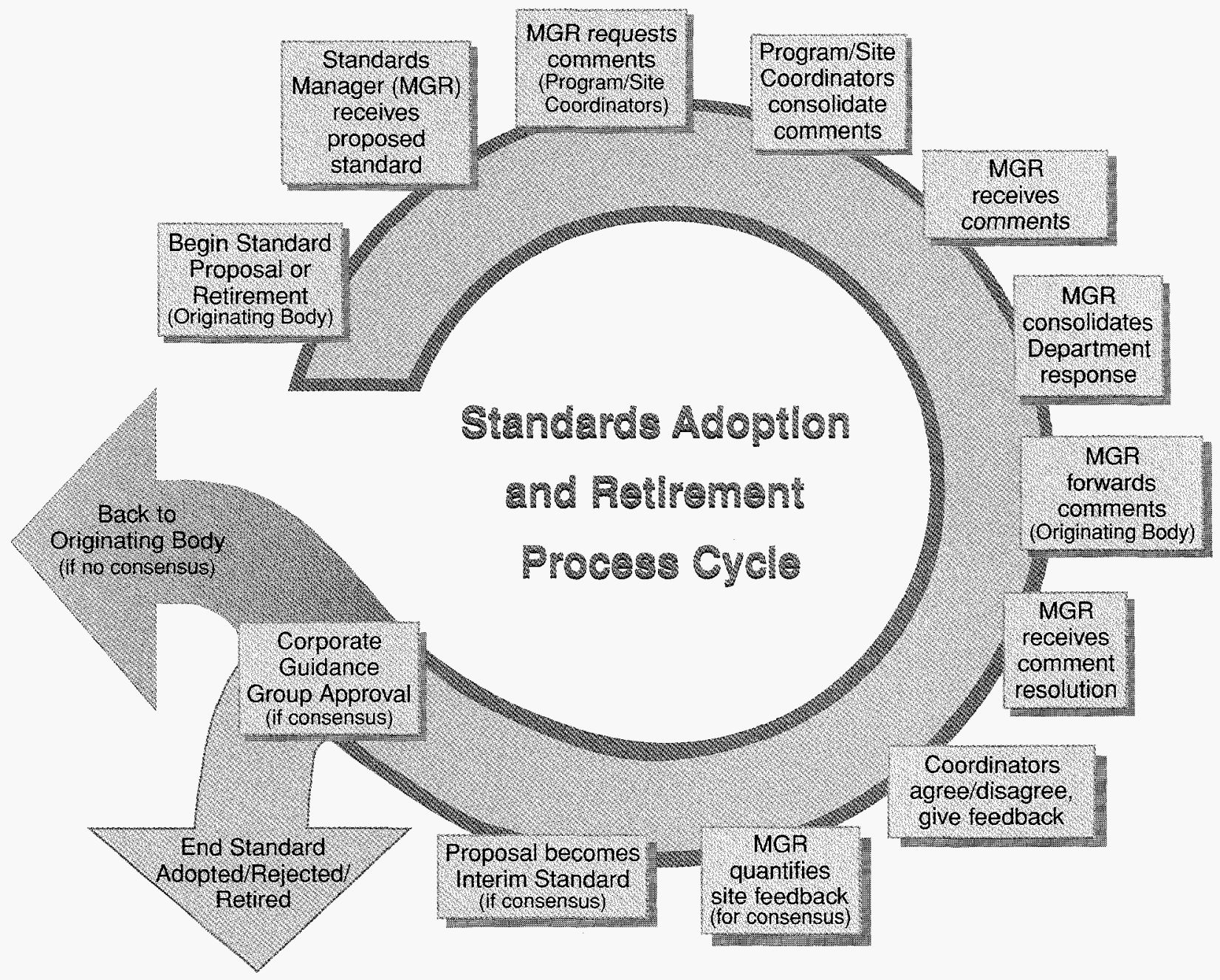









\section{Approach}

This Service Action Plan was developed to promote and facilitate implementation of this Departmental process. Detailed guidance on internal and external Information Technology Standards Program and Process activities is being prepared. Information Technology Standards policy, guidance documents, and the Information Architecture Standards Repository (which provides standards customers and stakeholders with a searchable database of DOE candidate standards information) are available on the WWW at the DOE Information Technology Standards Home Page Universal Resource Locator listed below.

\section{COMMUNICATION STRATEGY}

Effective communication is an essential element in the success of this activity. The following mechanisms will be used for communication among the Service Team, customers, and stakeholders.

$\square \quad$ DOE Information Technology Standards Home Page and Repository e-mail address: http:/www-it.hr.doe.gov/iat/itspro

$\square \quad$ Departmentwide Information Architecture Standards Workshops

$\sqsupset \quad$ IMPACT e-mail address: IMPACT@hq.doe.gov

$\square \quad$ List Server Technology: DOE IA Standards ListServ - Los Alamos; e-mail address: doe-ia-standards@lanl.gov

$\square \quad$ Information Architecture Home Page (http://www-it.hr.doe.gov/iat)

$\square \quad$ Technical Standards Home Page e-mail address:

http://apollo.osti.gov/html/techstds/techstds.html

】 IT Standards e-mail address: ITS-POCS@hq.doe.gov

$\square \quad$ Facsimile Technology

ஏ Telephone

$\square \quad$ Videotaping of Information Architecture meetings

$\square \quad$ Video Teleconferencing
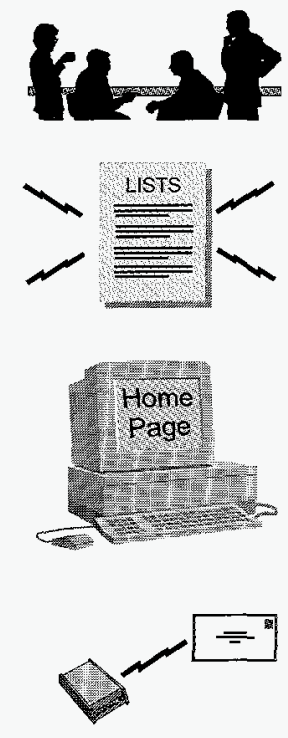
The following reference documents are available and can be downloaded from the WWW or obtained from the responsible office by the Service Team and any other information architecture customers. Draft documents are currently being finalized for publication and distribution.

$\square \quad$ DOE Information Architecture, Volume I, The Foundations, March 1995

$\square \quad$ DOE Information Architecture Standards Workshop Summary, May 1995

$\square$ DOE Information Management Standards Program and Process Guide (Draft), March 1996

$\square$ DOE Information Architecture, Volume II, Baseline Analysis Summary, December 1996

$\square \quad$ DOE Information Architecture Profile of Adopted Standards (Draft), April 1997

$\square \quad$ The Standards Forum - Available from the DOE Technical Standards Program Office

$\square \quad$ Standards Actions - Available from the DOE Technical Standards Program Office

\section{AUDITING THE SERVICE}

Auditing is being performed informally using e-mail and telephone. Formal auditing will be performed from the Information Technology Standards Home Page. It will include Site Visitation Statistics, a Who Visits log, and an online user feedback mechanism for comments or updates to the Information Technology Standards Points of Contact list.

As the process matures, the Service Team will work with customers to ensure the process meets their needs. Cycles of Service will be developed to audit the process and determine if process improvements are required. 


\section{CUSTOMER FEEDBACK}

Four IMPACT meetings have been held in the past 2 years. These meetings provide a forum for regular customer feedback on information architecture issues. At each session, participants were tasked to provide feedback and reminded that the information architecture process must be consensus-based. Sessions were captured on video to provide a visual gauge of the atmosphere surrounding these important events.

At the IMPACT IV meeting held in Santa Fe, New Mexico, in May 1996, a substantial amount of information architecture and related standards guidance were gathered. Future IMPACT meetings are planned to provide opportunities to further develop and refine the DOE information architecture and related standards.

Routine customer feedback is achieved primarily via e-mail and WWW Home Page mechanisms. Feedback will be used to determine customer satisfaction with the process and its standards and to further refine the process.

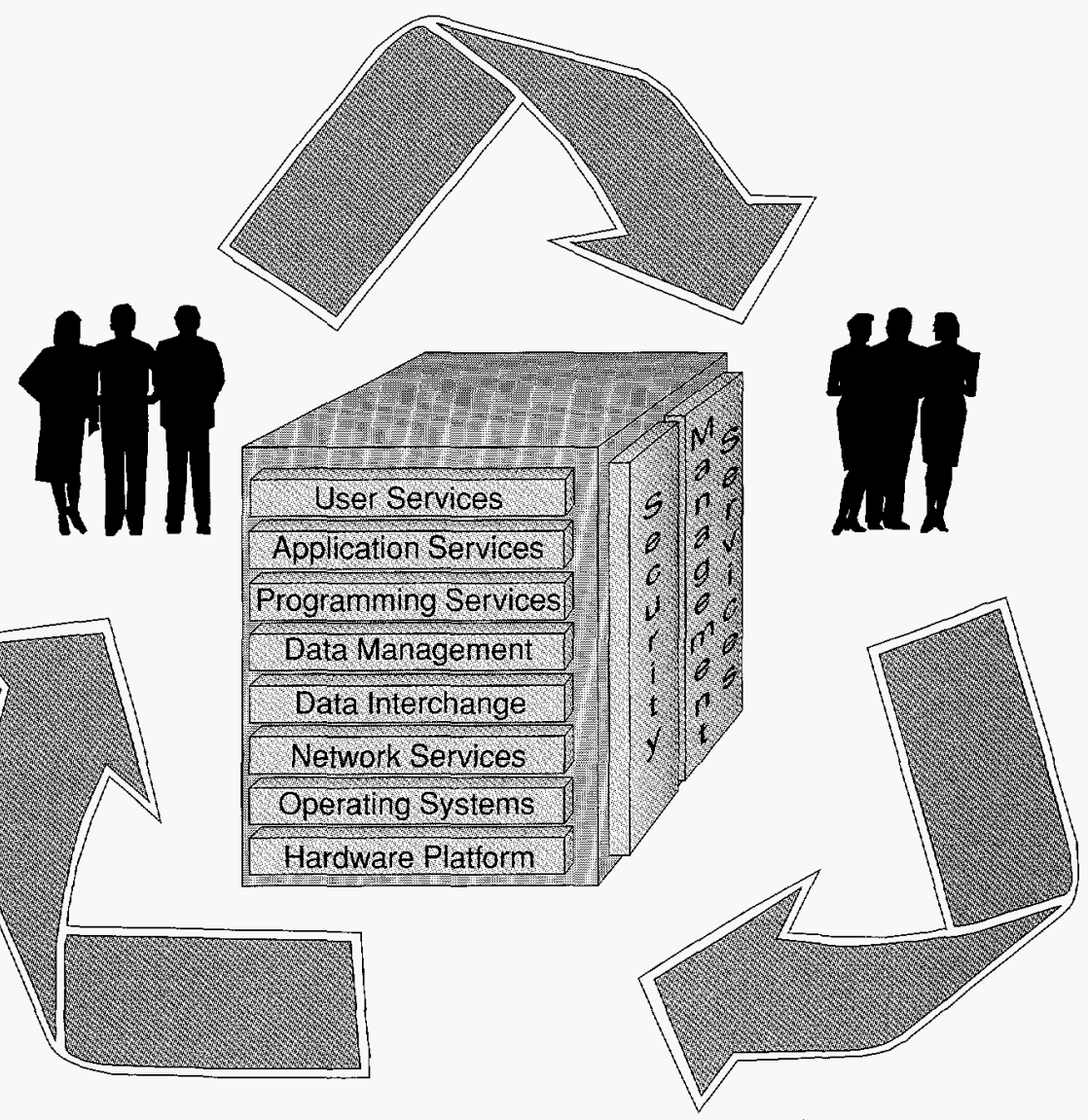




\section{EMPOWERMENT PLAN}

Information technology standards subject matter experts and affinity groups are empowered to propose the adoption and retirement of information technology standards for the DOE information architecture. The DOE Televideo Services User Group (DTSUG) and the DOE Digital Signature Working Group (DISIWG) are examples of DOE affinity groups.

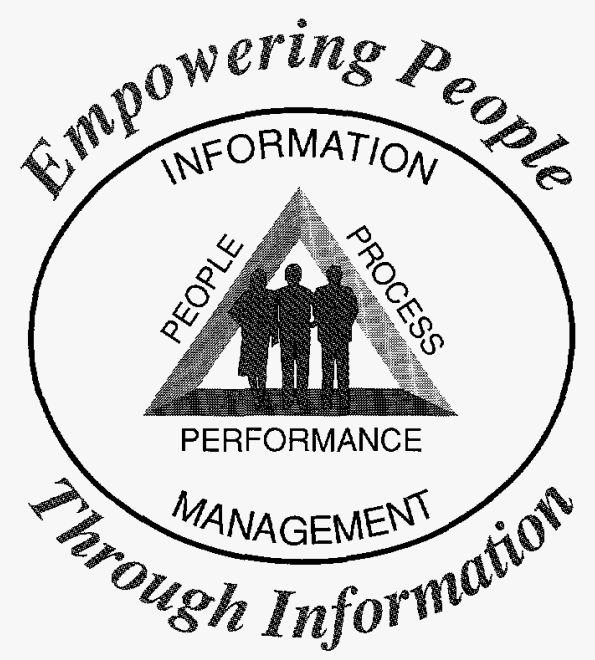

\section{REINFORCEMENT (Rewards, Reminders, and Recognition)}

IMPACT members and other participants were recognized by the CIO for their efforts to develop the DOE information architecture and the standards adoption and retirement process at the initial IMPACT meeting (October 1994).

Subsequent IMPACT meetings have had high-profile visibility. The meeting participants have provided maximum effort to the workshop proceedings, resulting in the development of many beneficial products. These efforts are reinforced to IMPACT members and their management by DOE Information Architect, Michael Tiemann; DOE Information Technology Standards Program Manager, Carol Blackston; and the DOE Information Architecture Team (HR-431).

The Information Management Quality Incentive Awards Program will be used to recognize and reward the Service Team and customers. The Customer Award will be given to recognize outstanding performance in partnering with HR-4, Deputy Assistant Secretary for Information Management, in accomplishing the process goals. Various other types of awards will be given to recognize DOE Federal and management and operating contractor individuals, organizations, and teams/groups who make significant quality contributions to the DOE information architecture standards adoption and retirement process. 


\section{BENEFITS}

Prominent benefits from this process will be the Department's ability to accomplish the following:

$\square \quad$ Coordinate standards requirements of DOE affinity groups to ensure overall interoperability and interconnectivity among the broader DOE community.

- Select appropriate standards from among many within the marketplace.

$\square \quad$ Select a standard for a specific function where one does not currently exist or one has not been selected by a standard-setting organization.

$\square \quad$ Add value to existing standards.

$\square \quad$ Further delineate the DOE information architecture and its implementation throughout the Department.

\section{MEASURING SUCCESS}

Success of the process will depend on the active involvement of customers. Implementation of this process will provide a methodology for efficient proposal, evaluation, adoption, and retirement of information technology standards for Departmentwide application.

The most successful standards will be adopted as a result of a consensus-based process that actively involves the stakeholders. 


\section{APPENDIX A}

\section{INFORMATION TECHNOLOGY STANDARDS POINTS OF CONTACT}




\section{APPENDIX A \\ INFORMATION TECHNOLOGY STANDARDS POINTS OF CONTACT}

\begin{tabular}{|c|c|c|c|}
\hline ORGANIZATION & NAME & PHONE & E MAL /MALING ADDRESS \\
\hline HQ DOE CR-13 & W. Eckhardt & (301) 903-2330 & walter.eckhardt@hq.doe.gov \\
\hline HQ DOE DP-44 & P. A. Haynes & (301) 903-3984 & patricia.haynes@dp.doe.gov \\
\hline HQ DOE ED-4 & J. Shea & (202) 586-7898 & john.shea@hq.doe.gov \\
\hline HQ DOE EE-60 & L. Planet & (202) 586-0418 & louise.planet@hq.doe.gov \\
\hline HQ DOE EH-72 & P. Heinig & (301) 903-9850 & pat.heinig@hq.doe.gov \\
\hline HQ DOE El-73 & J. Casselberry & (202) 254-5348 & jay.casselberry@hq.doe.gov \\
\hline HQ DOE EM-143 & D. Biser & (301) 903-7902 & david.biser@em.doe.gov \\
\hline HQ DOE ER-62 & G. Hughes & (301) 903-5409 & gene.hughes@oer.doe.gov \\
\hline HQ DOE FE-122 & B. Ladesic & (301) 903-2640 & bob.ladesic@hq.doe.gov \\
\hline HQ DOE HR-43 & H. Lewis & (202) 586-0168 & howard.lewis@hq.doe.gov \\
\hline HQ DOE HR-431 & C. Blackston & (301) $903-4294$ & carol.blackston@hq.doe.gov \\
\hline HQ DOE HR-431 & D. Berkau & (301) 903-3193 & dave.berkau@hq.doe.gov \\
\hline HQ DOE HR-431 & H. Clark & (301) $903-2507$ & helen.clark@hq.doe.gov \\
\hline HQ DOE HR-432 & B. White & (301) 903-6977 & bruce.white@hq.doe.gov \\
\hline HQ DOE HR-432 & M. Tiemann & (202) 586-5461 & michael.tiemann@hq.doe.gov \\
\hline HQ DOE HR-433 & M. Bahadori & $(301) 903-5988$ & mahmood.bahadori@hq.doe.gov \\
\hline HQ DOE HR-443 & P. Grahn & (301) $903-4653$ & peter.grahn@hq.doe.gov \\
\hline HQ DOE IG-13 & R. Jacques & (202) 586-3223 & robert.jacques@hq.doe.gov \\
\hline HQ DOE NE-10 & A. Sirulnik & (301) 903-5578 & arnie.sirulnik@hq.doe.gov \\
\hline HQ DOE NE-60 & W. Engel & (703) 603-5541 & engel_walter@hq.navsea.navy.mil \\
\hline HQ DOE NN-10 & J. Greenhill & (301) 903-8779 & john.greenhill@hq.doe.gov \\
\hline HQ DOE RW-15 & R. Wells & (202) 586-5003 & bob.wells@hq.doe.gov \\
\hline DOE - Albuquerque & J. Rimmer & $(505) 845-5320$ & jrimmer@doeal.gov \\
\hline DOE - Bonneville Power Admin & A. Herkamp & (503) 230-3406 & aaherkamp@bpa.gov \\
\hline DOE - Brookhaven Area Office & Standards Mgr & Not Available & 53 Bell Avenue, Upton, NY 11973 \\
\hline DOE - Carlsbad WIPP & M. Milligan & (505) 234-7340 & milligm@wipp.carlsbad.nm.us \\
\hline DOE - Chicago & D. Dyxin & (708) 252-2408 & donna.dyxin@ch.doe.gov \\
\hline DOE - Idaho & R. Rose & (208) 526-9666 & rosert@inel.gov \\
\hline
\end{tabular}




\begin{tabular}{|c|c|c|c|}
\hline ORGANIZATION & NAME & PHONE & E-MAIL/MAILING ADDRESS \\
\hline DOE - Naval Petroleum Reserve - CA & J. Kaiser & (805) $763-6037$ & P.O. Box 11, Tupman, CA 93276 \\
\hline DOE - Naval Petroleum Reserve & G. Coffey & (307) $261-5161$ & greg coffey at NPOSR-CUW \\
\hline DOE - Nevada & D. Hafen & (702) 295-1112 & hafen@nv.doe.gov \\
\hline DOE - Oak Ridge & G. Farzanegan & (423) $576-1112$ & farzanegangw@oro.doe.gov \\
\hline DOE - Oak Ridge & E. Hicks & (423) $756-1113$ & hicksej@oro.doe.gov \\
\hline DOE - Oakland & C. Boes & $(510) 637-1632$ & charles.boes@oak.doe.gov \\
\hline DOE - Oakland & O. Burks & $(510) 637-1738$ & dru.burks@oak.doe.gov \\
\hline DOE - OSTI & K. Hohenbrink & (423) $576-1160$ & ken.hohenbrink@ccmail.osti.gov \\
\hline DOE - OSTI & D. LaVerne & (423) 576-1148 & doug.laverne@ccmail.osti.gov \\
\hline DOE - Pittsburgh Naval Reactor & Standards Mgr & Not Available & P.O. Box 109, West Mifflin, PA 15122-0109 \\
\hline DOE - Richland & T. Schmeeckle & (509) $376-2964$ & T_O_Theo_Schmeeckle@rl.gov \\
\hline DOE - Savannah River & J. Hubbs & (803) $725-7344$ & jeffrey.hubbs@srs.gov \\
\hline DOE - Savannah River & R. Jernigan & $(803) 725-2685$ & P.O. Box A, Aiken, SC \\
\hline DOE - Savannah River & S. Morris & $(803) 725-3846$ & sarah.morris@srs.gov \\
\hline DOE - SEPA & Tech Librarian & (706) $213-3820$ & wadeg@wapa.gov \\
\hline DOE - SPRO & J. O'Brien & $(504) 734-4560$ & john.o'brien@spr.doe.gov \\
\hline DOE - SPRO & Prog Mgt Office & Not Available & 900 Commerce Rd E, New Orleans, LA 70123 \\
\hline DOE - SWPA (Goiden) & Tech Librarian & Not Available & 13949 W. Colfax, Golden, CO 80401 \\
\hline DOE - SWPA (Tulsa) & Tech Librarian & Not Available & P.O. Box 1619 , Tulsa, OK 74103 \\
\hline AlliedSignal, Inc. & L. Wood & (816) $997-4783$ & Iwood@kcp.com \\
\hline AlliedSignal, Inc. & M. Smith & $(816) 997-3590$ & msmith@kcp.com \\
\hline Argonne National Laboratory & C. Beck & (708) 252-7735 & clbeck@anl.gov \\
\hline Argonne National Laboratory & R. Hrabak & (708) 252-9305 & rhrabak@anl.gov \\
\hline Barge-Waggoner Sumner Canada & B. Claiborne & Not Available & 8755 Gander Crk, Miamisburg, OH 45342 \\
\hline Barge-Waggoner Sumner Canada & S. Fritts & (423) 574-1286 & 1093 Commerce Pk. Dr., Oak Ridge, TN 37831 \\
\hline Battelle Memorial Institute & D. Mann & (703) 575-0143 & mannd@battelle.org \\
\hline Bechtel Petroleum Operations & IS Dept Mgr & Not Available & hqccmail-nprcdoe \\
\hline Bechtel Services Nevada & D. Belangia & (702) 295-0431 & belangdw@nv.doe.gov \\
\hline Brookhaven National Laboratory & A. Peskin & $(516) 344-4161$ & peskin@bnl.gov \\
\hline DynCorp & O. Santivanez & (301) 903-0852 & sandy.santivanez@hq.doe.gov \\
\hline DynMcDermott Petroleum Ops & B. Wood & (504) $734-4893$ & bill.wood@spr.doe.gov \\
\hline EG\&G Mound Applied Technology & P. Bantz & $(513) 865-3090$ & bantpd@doe-md.gov@wins@aos1 \\
\hline
\end{tabular}

Standards Adoption and

Retirement Process

$3 / 97$
A-2

Department of Energy Information Architecture 


\begin{tabular}{|c|c|c|c|}
\hline ORGANIZATION & NAME & PHONE & E-MAIL/MAILING ADDRESS \\
\hline EG\&G Mound Applied Technology & R. Benson & (513) 252-3967 & bensra@doe-md.gov@wins@aos1 \\
\hline Environ Measurements Laboratory & C. Marinetti & (212) 620-3272 & cgm@eml.doe.gov \\
\hline Fermi National Accelerator Laboratory & J. Pfister & (708) 840-3926 & jack_pfister@qmgate.fnal.gov \\
\hline Fermilab & I. Gaines & (708) 840-4022 & gaines@fnal.gov \\
\hline Fermilab & T. Nash & (708) 840-3211 & nash@fnal.gov \\
\hline KENROB and Associates & L. Scanlan & (702) 794-5529 & lorita_scanlan@notes.ymp.gov \\
\hline Los Alamos National Laboratory & L. Kroggel & $(505) 665-6011$ & Ikroggel@lanl.gov \\
\hline Los Alamos National Laboratory & C. Ostenak & $(505) 667-5911$ & carlo@lanl.gov \\
\hline Los Alamos National Laboratory & D. Weir & (505) 667-9337 & drw@lani.gov \\
\hline Lawrence Berkeley Laboratory & C. Backhus & $(510) 486-6307$ & cdbackhus@lbl.gov \\
\hline Lawrence Berkeley Laboratory & L. Chen & (510) 486-6117 & ljchen@lbl.gov \\
\hline Lawrence Livermore National Laboratory & Comput Dpt & Not Available & P.O. Box 808, Livermore, CA 94551 \\
\hline Lawrence Livermore National Laboratory & D. P. Grubb & $(510) 423-4745$ & dgrubb@IInl.gov \\
\hline Lawrence Livermore National Laboratory & F. Norton & (510) $422-0491$ & fred.norton@quickmail.IInl.gov \\
\hline Lockheed-Martin Energy Systems & S. Jordan & (423) 574-5368 & jordansr@ornl.gov \\
\hline Mason \& Hanger-Silas Mason & C. Brown & (806) $477-3270$ & cbrown@pantex.com \\
\hline Morgantown Energy Technology Center & J. Craig & (304) $285-4178$ & jcraig@metc.doe.gov \\
\hline New York University & E. Hockberg & (212) $998-1212$ & hockberg@nyu.edu \\
\hline Pantex & M. Andrew & (806) 477-3554 & mandrew@pantex.com \\
\hline Parsons & B. Knutson & (513) 648-6714 & 6120 Gilmore Road, Fairfield, $\mathrm{OH} 45246-3700$ \\
\hline Pacific Northwest National Laboratory & L. Skelly & (202) 646-5260 & I_skelly@ccmail.pnl.gov \\
\hline Princeton Plasma Physics Laboratory & Tech Librarian & Not Available & P.O. Box 451, Princeton, NJ 08543 \\
\hline Sandia National Laboratories & L. West & (510) 294-2476 & lawest@sandia.gov \\
\hline Stanford Linear Accelerator Center & J. Dixon & (415) 926-3688 & dixon@slac.stanford.edu \\
\hline Stanford Linear Accelerator Center & W. Johnson & (415) $926-2660$ & wbj@slac.stanford.edu \\
\hline Westinghouse Savannah River & D. Gordon & (803) $725-1817$ & donald03.gordon@srs.gov \\
\hline Westinghouse Savannah River & R. Frontroth & (803) 725-5305 & ronald.frontroth@srs.gov \\
\hline
\end{tabular}

Department of Energy

Information Architecture 
Notes 